\title{
Kontaminasi Aflatoksin dan Fumonisin dalam Pakan Ayam Pedaging
}

\author{
(Aflatoxin and Fumonisin Contamination in Broiler Feed)
}

\author{
Widiyanti PM, Maryam R \\ Balai Besar Penelitian Veteriner, Jl. RE Martadinata No. 30, Bogor 16114 \\ primamw@gmail.com
}

\begin{abstract}
Aflatoxin and fumonisin are secondary metabolites of molds that can cause health problems in animals and humans. The purpose of this study was determined the level of aflatoxin and fumonisin contamination in broiler feed. Analysis of aflatoxin and fumonisin conducted using Enzyme Linked Immunosorbent Assay (ELISA) method. Samples were extracted using methanol and then analyzed by ELISA method and detected using ELISA reader at a wavelength of $450 \mathrm{~nm}$. The concentration of aflatoxin and fumonisin in the samples were calculated using the equation of the line generated by the standard curve (concentration vs \% inhibition). Results of aflatoxin B1 levels ranged 0.50 to $39.40 \mathrm{ppb}$; mean $7.63 \mathrm{ppb}$, and fumonisin levels ranged 57.57 to $368.48 \mathrm{ppm}$; mean $159.90 \mathrm{ppm}$. The concentration of aflatoxin in broiler feeds were under of SNI regulations $(50 \mathrm{ppb})$, while $5,7 \%$ samples were above of FDA regulation $(20 \mathrm{ppb})$. The concentration of fumonisin in $63 \%$ broiler feeds showed the results above of FDA regulations (100 ppm).
\end{abstract}

Key Words: Aflatoxin, Fumonisin, Broiler Feed

\begin{abstract}
ABSTRAK
Aflatoksin dan fumonisin merupakan metabolit sekunder dari kapang yang dapat menyebabkan gangguan kesehatan pada hewan dan manusia. Tujuan dari penelitian ini adalah untuk mengetahui tingkat kontaminasi aflatoksin dan fumonisin pada pakan ayam pedaging. Analisa kadar aflatoksin dan fumonisin dilakukan dengan metode Enzyme Linked Immunosorbent Assay (ELISA). Sampel diekstraksi terlebih dahulu dengan metanol kemudian dianalisa dengan menggunakan metode ELISA lalu hasilnya dibaca dengan ELISA reader dengan panjang gelombang $450 \mathrm{~nm}$. Konsentrasi aflatoksin dan fumonisin dalam sampel dihitung dengan menggunakan persamaan garis yang dihasilkan oleh kurva standar (konsentrasi vs \% inhibisi). Hasil analisa kadar aflatoksin B1 dari 35 sampel berkisar antara 0,50-39,40 ppb dengan rataan 7,63 ppb, sedangkan kadar fumonisin total berkisar antara 57,57-368,48 ppm dengan rataan 159,90 ppm. Konsentrasi aflatoksin dalam pakan ayam pedaging masih dibawah regulasi yang ditetapkan SNI (50 ppb), sedangkan 5,7\% sampel diatas regulasi yang ditetapkan FDA (20 ppb). Konsentrasi fumonisin pada 63\% sampel pakan menunjukkan hasil diatas regulasi yang ditetapkan FDA (100 ppm).
\end{abstract}

Kata Kunci: Aflatoksin, Fumonisin, Pakan Ayam Pedaging

\section{PENDAHULUAN}

Pakan merupakan sumber nutrisi utama hewan dan merupakan faktor penting dalam proses kehidupan hewan. Pakan berperan dalam pertumbuhan, pertahanan hidup, menghasilkan produk hewan, dan untuk memelihara daya tahan tubuh serta kesehatan hewan. Kuantitas dan kualitas produk pakan yang baik akan berpengaruh terhadap produk pangan asal hewan yang dihasilkan. Beberapa faktor yang mempengaruhi kualitas pakan antara lain bentuk fisik, nutrisional dan keamanan. Keamanan pakan dari potensi bahaya fisik, biologi dan kimiawi sebaiknya perlu mendapat perhatian. Salah satu faktor yang 
dapat mempengaruhi keamanan pakan adalah kontaminasi mikotoksin (Achmadi 2010; Ahmad 2009; Suparto 2004).

Mikotoksin merupakan metabolit sekunder dari kapang toksigenik genus Aspergillus, Penicillium dan Fussarium. Jenis mikotoksin antara lain aflatoksin, okratoksin, fumonisin, trikotesena, deoksinivalenol dan zearalenon (Lattanzio et al. 2007; EFSA 2009; Saeger 2011). Aflatoksin dan fumonisin merupakan jenis mikotoksin yang dapat mengkontaminasi biji-bijian, bahan pakan dan pakan. Aflatoksin memiliki toksisitas yang tinggi dan menjadi permasalahan dalam peternakan serta menyebabkan kerugian ekonomi (Siloto et al. 2013). Aflatoksin (Aflatoksin B1, B2, G1, G2) dihasilkan dari kapang Aspergillus flavus dan A. parasiticus. Aflatoksin dapat menyebabkan gangguan kesehatan, antara lain penurunan nafsu makan, berat badan, pertumbuhan, produksi telur dan kekebalan tubuh (Ortatatli et al. 2004; Zain 2010). Aflatoksin B1 merupakan senyawa toksik yang paling berbahaya dan dikategorikan sebagai senyawa karsinogenik group IA. Paparan dosis tinggi menyebabkan keracunan akut, yang dapat menyebabkan kematian, sementara paparan dosis rendah dalam waktu lama akan menimbulkan efek karsinogenik. Pada keracunan akut, terjadi kegagalan metabolisme karbohidrat dan lemak serta sintesa protein pada hati, sehingga terjadi penurunan fungsi hati karena adanya perombakan pembekuan darah, dan penurunan sintesa protein serum. Pada keracunan kronik akan menyebabkan immunosupresif yang diakibatkan penurunan aktivitas vitamin $\mathrm{K}$ dan penurunan aktivitas fagositas pada makrofak (Bommakanti 2006).

Fumonisin merupakan mikotoksin yang dihasilkan oleh Fusarium spp. seperti $F$. subglutinans, $F$. verticillioides dan $F$. proliferatum. Keberadaan fumonisin pada produk pertanian, bahan pakan dan pakan sangat merugikan, karena selain menurunkan kualitas produk pertanian yang dapat mempengaruhi nilai ekonomi, juga dapat menimbulkan berbagai penyakit pada manusia atau hewan yang mengkonsumsinya (Maryam 2000). Terdapat 28 jenis fumonisin yang terbagi menjadi 4 kelompok besar yaitu fumonisin A, B, C, dan P. Kelompok fumonisin B (B1, B2, B3) paling banyak ditemukan di alam dan paling toksik (Maryam 2007). Fumonisin B1 memiliki toksisitas tinggi, dapat menghambat kerja enzim sfinganin (sfingosin) $\mathrm{N}$-asiltransferase yang berpengaruh dalam menginduksi kematian sel pada ginjal (Ahmad 2009). Organ yang terpapar oleh fumonisin ditandai dengan adanya akumulasi sfingoid bebas dalam serum dan urin. Fumonisin dapat menimbulkan penurunan nafsu makan, gangguan pernafasan, serta kelainan pada organ hati dan ginjal (Merril et al. 2001). Fumonisin juga dapat menyebabkan penurunan kalsium dan peningkatan klorida pada serum (Broomhead et al. 2002).

Efek toksik dari mikotoksin bervariasi, karena sifat kimia, biologik dan toksikologiknya berbeda-beda. Selain itu toksisitas mikotoksin ditentukan juga oleh dosis atau jumlah mikotoksin yang dikonsumsi, rute dan lamanya pemaparan, spesies, umur, jenis kelamin, status kesehatan dan gizi, serta efek sinergis dari berbagai mikotoksin yang secara bersamaan terdapat pada pangan, pakan, bahan pangan dan bahan pakan (Eijk 2003; Kolossova et al. 2009). Menurut Harvey et al. (1995) dan Liu et al. 2002 dalam Pedrosa \& Borutova (2011) keberadaan aflatoksin dan fumonisin secara bersamaan di dalam pakan atau bahan pakan dapat menimbulkan efek sinergis pada ternak babi. Hal ini perlu diwaspadai karena efek sinergis dari kedua mikotoksin tersebut dapat meningkatkan toksisitas sehingga diperlukan kepedulian terhadap keamanan pakan yang dapat berpengaruh terhadap kesehatan hewan dan manusia (Binder et al. 2007).

Tujuan dari penelitian ini adalah untuk mengetahui tingkat kontaminasi aflatoksin dan fumonisin pada pakan ayam pedaging sehingga dapat diketahui apakah kadarnya masih dalam batas regulasi yang telah ditetapkan serta aman diberikan pada hewan. 


\section{MATERI DAN METODE}

\section{Analisis aflatoksin pada sampel pakan}

\section{Ekstraksi}

Sebanyak 35 sampel pakan ayam pedaging berasal dari peternakan di wilayah Kabupaten Bogor. Kemudian masing-masing sampel dianalisa. Sampel pakan digiling, sebanyak 25 gram sampel diekstrak dengan $100 \mathrm{ml}$ metanol-akuades $60 \%$, dikocok selama 30 menit dengan menggunakan shaker, lalu disentrifus $3000 \mathrm{rpm}$ selama 15 menit. Cairan jernih (supernatan) diambil untuk dianalisis.

\section{Enzyme linked immunosorbent assay (ELISA)}

Analisis aflatoksin dalam sampel pakan dilakukan dengan menggunakan metode Enzyme Linked Immunosorbent Assay (ELISA) yang telah dikembangkan di BB Litvet (Rachmawati et al. 2004). Sebelum dilakukan analisis, pereaksi yang digunakan dikondisikan pada suhu ruang. Substrat disiapkan dengan menambahkan $30 \mu 1$ substrat B ke dalam $970 \mu \mathrm{l}$ substrat A. Pada pelat pencampur dimasukkan $70 \mu 1$ standar AFB1 pada masing-masing lubang secara berurutan mulai dari blanko, konsentrasi rendah sampai tertinggi $(0 ; 0,1 ; 0,37 ; 1,1 ; 3,3 ; 10 ; 30 \mathrm{ppb})$, metanol (tanpa konjugat) dan sampel. Setelah itu ditambahkan $140 \mu \mathrm{l}$ larutan konjugat kedalam tiap lubang dan dihomogenkan dengan menggunakan pipet multi channel, kemudian dipindahkan $75 \mu \mathrm{l}$ ke dalam pelat berlapis antibodi dengan 2 ulangan. Pelat diinkubasi selama 30 menit, larutan dibuang dan dicuci dengan akuades tiga kali, selanjutnya ditambahkan $100 \mu \mathrm{l}$ substrat yang telah dicampur dan diinkubasi kembali selama 15 menit. Selanjutnya ditambahkan $50 \mu 1$ larutan penghenti reaksi, dan pelat dibaca pada alat pembaca ELISA (ELISA reader) dengan panjang gelombang $450 \mathrm{~nm}$. Hasil pembacaan dan konsentrasi aflatoksin dalam sampel dihitung dengan menggunakan persamaan garis yang dihasilkan oleh kurva standar (konsentrasi vs persentase inhibisi).

\section{Analisis fumonisin pada sampel pakan}

\section{Ekstraksi}

Sampel pakan digiling, sebanyak $25 \mathrm{~g}$ sampel diekstrak dengan $100 \mathrm{ml}$ metanolakuades $60 \%$, dikocok selama 30 menit dengan menggunakan shaker, lalu disentrifus 3000 rpm selama 15 menit. Cairan jernih bagian atas (supernatan) dimasukkan ke dalam tabung $15 \mathrm{ml}$, lalu dipipet $50 \mu \mathrm{l}$ dan dimasukkan ke dalam eppendorf, diencerkan dengan aquades hingga volume $1 \mathrm{ml}$ untuk dianalisis.

\section{Enzyme Linked Immunosorbent Assay (ELISA)}

Analisis fumonisin dalam sampel pakan dilakukan dengan menggunakan ELISA kit yang telah dikembangkan Roomer Labs (Romer Labs 2007). Sebelum dilakukan analisa, pereaksi yang digunakan dikondisikan pada suhu ruang. Pada pelat pencampur dimasukkan $100 \mu \mathrm{l}$ standar fumonisin pada masing-masing lubang secara berurutan mulai dari blanko, konsentrasi rendah sampai tertinggi $(0 ; 0,25 ; 1 ; 2,5 ; 5 \mathrm{ppm})$, metanol (tanpa konjugat) dan sampel. Ditambahkan $200 \mu$ l larutan konjugat ke dalam tiap lubang dan dihomogenkan dengan menggunakan pipet multi channel, kemudian dipindahkan $100 \mu 1$ ke dalam pelat berlapis antibodi dengan 2 ulangan. Pelat diinkubasi selama 10 menit, 
larutan dibuang dan dicuci dengan akuades lima kali, selanjutnya ditambahkan $100 \mu 1$ substrat yang telah dicampur dan diinkubasi kembali selama lima menit. Selanjutnya, ditambahkan $100 \mu 1$ larutan penghenti reaksi, dan pelat dibaca pada alat pembaca ELISA (ELISA reader) dengan panjang gelombang $450 \mathrm{~nm}$. Hasil pembacaan dan konsentrasi aflatoksin dalam sampel dihitung dengan menggunakan persamaan garis yang dihasilkan oleh kurva standar (konsentrasi vs persentase inhibisi).

\section{HASIL DAN PEMBAHASAN}

Hasil analisis aflatoksin dan fumonisin (Tabel 1) dengan menggunakan metode ELISA menunjukkan bahwa konsentrasi aflatoksin B1 pada pakan ayam pedaging berkisar antara 0,50-39,40 ppb dengan rata-rata 7,63 ppb, sedangkan hasil analisis konsentrasi fumonisin total berkisar antara 33,22-368,48 ppm dengan rata-rata 159,90 ppm. Konsentrasi aflatoksin B1 pada 35 sampel masih di bawah regulasi yang telah ditetapkan Standar Nasional Indonesia (SNI) dengan batas maksimum residu (BMR) 50 ppb, namun 2 dari 35 sampel (5,7\%) melebihi regulasi yang ditetapkan Food and Drug Administration (FDA) dengan batas maksimum residu (BMR) $20 \mathrm{ppb}$. Konsentrasi fumonisin (B1, B2, B3) pada 22 dari 35 sampel (63\%) melebihi regulasi yang ditetapkan Food and Drug Administration (FDA) dengan batas maksimum residu (BMR) $100 \mathrm{ppm}$. Penelitian di Turki pada jagung untuk pakan ternak menunjukkan kontaminasi aflatoksin total berkisar antara 0,01-32,30 ppb, dengan rataan 10,94 ppb dan fumonisin total dari 0,80-356,8 ppm, dengan rataan 88,24 ppm (Oruc et al. 2006). Penelitian pada pakan ternak di Korea selatan, pakan ayam terkontaminasi fumonisin B1 (78\%) dan fumonisin B2 (40\%), pakan sapi FB1 (100\%), FB2 (80\%), pakan babi FB1 (76\%) dan pada FB2 (22\%) (Seo et al. 2013). Pada sampel jagung di Camerun terkontaminasi aflatoksin dengan kadar <2-42 ppb, pada kacang tanah 39-950 ppb, pada pakan ayam pedaging 2-52 ppb dan pada pakan ayam petelur 2-23 ppb (Kana et al. 2013). Penelitian pada 3.230 sampel yang meliputi sayuran, bahan pakan dan pakan ternak unggas terdeteksi aflatoksin B1 dengan kisaran 13-78 ppb (Bhatti et al. 2001). Penelitian lainnya di Indonesia, kontaminasi fumonisin B1 pada pakan ayam paling tinggi mencapai 30,16 ppm (Maryam 2000). Hal ini menunjukkan bahwa kontaminasi aflatoksin dan fumonisin banyak terjadi dan perlu mendapat perhatian agar lebih meningkatkan keamanan pakan yang akan berpengaruh terhadap kesehatan hewan dan manusia.

Tabel 1. Kadar aflatoksin B1 dan fumonisin B1, B2, B3 pada sampel pakan

\begin{tabular}{llcc}
\hline \hline $\begin{array}{l}\text { Jenis dan jumlah } \\
\text { sampel }\end{array}$ & Jenis mikotoksin & Kisaran hasil analisa & Rata-rata \\
\hline Pakan ayam & Aflatoksin B1 & $0,50-39,40 \mathrm{ppb}$ & $7,63 \mathrm{ppb}$ \\
pedaging $(\mathrm{n}=35)$ & Fumonisin B1, B2, B3 & $33,22-368,48 \mathrm{ppm}$ & $159,90 \mathrm{ppm}$ \\
\hline
\end{tabular}

Kontaminasi kapang yang dapat menghasilkan aflatoksin dan fumonisin dapat terjadi karena beberapa faktor, antara lain iklim (suhu dan kelembaban), jenis tanaman, kondisi tanah serta ketersediaan nutrisi dalam tanah (Strosnider et al. 2006; Nyangi 2016). Cemaran kapang dapat berpengaruh pada bahan pakan karena menyebabkan perubahan warna, kehilangan bobot, kontaminasi mikotoksin, serta kerusakan total. Bahan baku pakan seperti jagung dan biji-bijian dapat terkontaminasi oleh kapang sebelum, ketika dan sesudah masa panen. Faktor lingkungan dan kerusakan oleh serangga, proses pemanenan serta kondisi penyimpanan akan berpengaruh terhadap tingkat kontaminasi (Ahmad 2009). Penyimpanan dengan kondisi buruk dapat berpengaruh terhadap kontaminasi aflatoksin 
dan fumonisin. Hasil pengujian aflatoksin pada sampel jagung yang dipasarkan di Caroline utara mengandung aflatoksin hingga 1300,3 ppb dan fumonisin hingga 148,3 ppm (Johansson et al. 2006). Penyimpanan sampel yang sudah terlalu lama (pakan ayam pedaging yang disimpan selama 42 hari) berpengaruh terhadap peningkatan konsentrasi fumonisin (Maryam 2007). Faktor lainnya yang dapat mempengaruhi kontaminasi mikotoksin yaitu proses penanaman dan pemanenan biji-bijian sebagai bahan baku pakan, transportasi, pengolahan atau produksi pakan dan suhu serta kelembaban ditempat penyimpanan pakan (Goncalves et al. 2015).

Aflatoksin dan fumonisin yang mengkontaminasi pakan secara bersamaan memiliki efek sinergis sehingga toksisitasnya menjadi lebih tinggi dan dapat mengganggu kesehatan hewan (Pedrosa \& Borutova 2011). Penelitian pada pakan yang diberi aflatoksin dan fumonisin mengakibatkan efek kesehatan pada unggas diantaranya penurunan berat badan, konsentrasi albumin, total protein, kolesterol serta pembengkakan pada limpa (Weibking et al. 1994). Kontaminasi aflatoksin B1 dan fumonisin B1 dapat menyebabkan kerusakan hati dan ginjal serta dapat menyebabkan kanker pada hewan dan manusia (Del Bianchi et al. 2005; Bruns 2003).

Kontaminasi mikotoksin dapat dicegah dengan penerapan manajemen yang baik (good management practices) dimulai dari proses penanaman, pemanenan dan penyimpanan produk pertanian (Grenier \& Applegate 2012). Manajemen pencegahan dan teknologi dekontaminasi untuk mengurangi efek mikotoksin juga perlu dikembangkan, dengan cara fisik (pencucian, pemanasaan, radiasi ultraviolet), pencegahan kontaminasi (penanaman, pemanenan, penyimpanan, dan distribusi), detoksifikasi dalam pakan ternak dengan penambahan feed aditif, penambahan bahan kimia (kalsium hidroksid, monoethilamin, amonia) dan bahan pengikat mikotoksin sehingga dapat menghasilkan produk pertanian, pakan dan pangan yang berkualitas serta terhindar dari kontaminasi mikotoksin (Kolossova et al. 2009).

\section{KESIMPULAN}

Konsentrasi aflatoksin pada pakan yang dianalisa masih di bawah batas regulasi, akan tetapi aflatoksin akan terakumulasi apabila pemberian pakan terus dilanjutkan, sedangkan konsentrasi fumonisin melebihi batas regulasi yang dapat memungkinkan terjadinya sinergisme kedua mikotoksin tersebut dapat menyebabkan mikotoksikosis pada ternak. Hal ini perlu diwaspadai karena dapat menyebabkan multi mikotoksikosis yang sangat merugikan dan menimbulkan residu mikotoksin pada produk ternak yang dapat membahayakan kesehatan masyarakat.

\section{DAFTAR PUSTAKA}

Achmadi J. 2010. Penjaminan mutu pakan berbasis HACCP. Disampaikan pada Koordinasi Pengawasan Mutu Pakan (Wastukan) Provinsi Jawa Tengah. Ungaran, 28 Juni 2010. Ungaran (Indonesia): Dinas Peternakan dan Kesehatan Hewan Propinsi Jawa Tengah. $7 \mathrm{hlm}$.

Ahmad RZ. 2009. Cemaran kapang pada pakan dan pengendaliannya. J Litbang Pertanian. 28:1522.

Bhatti BM, Talat T, Sarda R. 2001. Estimation of aflatoxin B1 in feed ingredients and compound poultry feeds. Pak Vet J. 21:57-60.

Binder EM, Tan LM, Chin LJ, Handl J, Richard J. 2007. Worldwide occurrence of mycotoxins in commodities, feeds and feed ingredients. Anim Feed Sci Technol. 137:265-282. 
Bommakanti AS, Waliyar F. 2006. Importance of aflatoxins in human and livestock health. [Internet]. [cited 5 Maret 2006]. Available from: http:/www.aflatoxin.info/health.asp.

Broomhead JN, Ledoux DR, Bermudez J, Rottinghaus GE. 2002. Chronic effects of fumonisin B1 in pedagings and turkeys fed dietary treatments to market age. Poult Sci. 81:56-61.

Bruns HA. 2003. Controlling aflatoxin and fumonisin in maize by crop management. Toxin Rev. 22:153-173.

Del Bianchi M, Oliveira CF, Albuquerque R, Guerra JL, Correa B. 2005. Effects of prolonged oral administration of aflatoxin B1 and fumonisin B1 in pedaging chickens. Poult Sci. 84:18351840 .

Eijk CVD. 2003. New technologies improve mycotoxin elimination. J Feed Mix. 11:8-10.

EFSA. 2009. Review of Mycotoxin-detoxifying agents used as feed additives: mode of action, efficacy and feed/food safety [Internet]. [cited 4 February 2014]. European Food Safety Authority. Available from: http://www.efsa.europa.eu/en/scdocs/doc/22e.pdf

FDA. 2011. Mycotoxin regulatory guidance: A guide for grain elevators, feed manufacturers, grain processors and exporters. Food and Drug Administration. Washington DC (USA): National Grain and Feed Association.

Goncalves BL, Corassin CH, Oliveira CAF. 2015. Mycotoxicoses in dairy cattle: A review. Asian J Anim Vet Adv. 10:752-760.

Grenier B, Applegate TJ. 2012. Reducing the impact of aflatoxins in livestock and poultry. [Internet]. [cited 4 Februari 2014] Available from: http://www.ag.purdue.edu/ANSC.

Johansson AS, Whitaker TB, Hagler WM, Bowman DT, Slate AB, Payne G. 2006. Predicting aflatoxin and fumonisin in shelled corn lots using poor-quality grade components. J AOAC Int. 89:433-440.

Kana JR, Gnonlonfin BGJ, Harvey J, Wainaina J, Wanjuki I, Skilton RA, Teguia A. 2013. Assessment of aflatoxin contamination of maize, peanut meal and poultry feed mixtures from different agroecological zones in Cameroon. J Toxins 5:884-894.

Kolossova A, Stroka J, Breidbach A, Kroeger K, Ambrosio M, Bouten K. 2009. Evaluation of the effect mycotoxin binders in animal feed on the analytical performance of standardised methods for the determination of mycotoxin in feed. JRC Eur. 54375:1-46.

Lattanzio UMT, Solfrizzo M, Powers S, Visconti A. 2007. Simultaneous determination of aflatoxins, ochratoxin A and fusarium toxins in maize by liquid chromatography/tandem mass spectrometry after multitoxin immunoaffinity cleanup. RCM Wiley Inscience. RCM Wiley Interscience. 21:3253-3261.

Maryam R. 2000. Kontaminasi fumonisin pada bahan pakan dan pakan ayam di Jawa Barat. Dalam: Haryanto B, Darminto, Hastiono S, Sutama IK, Partoutomo S, Subandriyo, Sinurat AP, Darmono, Supar, Butar-Butar SO, penyunting. Prosiding Seminar Nasional Peternakan dan Veteriner. Bogor, 18-19 September 2000. Bogor (Indonesia): Puslitbangnak. hlm. 538-542.

Maryam R. 2007. Produksi antibodi monoklonal menggunakan konjugat fumonisin B1 sebagai antigen untuk deteksi fumonisin secara imunoasai [Disertasi]. [Bogor (Indonesia)]: Institut Pertanian Bogor.

Merril JAH, Sullards MC, Wang E, Voss KA, Riley RT. 2001. Sphingolipid metabolism: Roles in signal transduction and disruption by fumonisins. Environ Health Perspect. 109:283-289.

Nyangi C, Mugula JK, Beed F, Boni S, Koyano E, Sulyok M. 2016. Aflatoxins and fumonisin contamination of marketed maize, maize bran and maize used as animal feed in Northern Tanzania. Afric J Food Agric. 16:11054-11065. 
Ortatatli M, Oguz H, Hatipoglu F, Karaman M. 2005. Evaluation of pathological changes in broilers during chronic aflatoxin (50 and $100 \mathrm{ppb}$ ) and clinoptilolite exposure. J Res Vet Sci. 78:61-68.

Oruc HH, Cengiz M, Kalkanli O. 2006. Comparison of aflatoxin and fumonisin levels in maize grown in Turkey and imported from the USA. Anim Feed Sci Technol. 128:337-341.

Pedrosa K, Burotuva R. 2011. Synergistic effects of mycotoxins discussed. J Feedstuffs. 83:1-3.

Rachmawati S, Lee A, Murdiati TB, Kennedy I. 2004. Pengembangan enzyme linked immunosorbent assay (ELISA) teknik untuk analisis aflatoksin B1 pada pakan ternak. Dalam: Prosiding Seminar Parasitologi dan Toksikologi Veteriner. Bogor, 20-21 April 2004. Bogor (Indonesia): Puslitbangnak. hlm. 143-160

Romer Labs. 2007. AgraQuant total fumonisin assay. [Internet]. [cited 5 Februari 2015]. Available from: http://www.autotrep.jp/kosou/pdf/AgraQuant\%20FUM\%20Method\% 20_0.255_010108 .pdf.

Saeger SD. 2011. Determining mycotoxins and mycotoxigenic fungi in food and feed. Cambridge (UK): Woodhead Publishing.

Seo DG, Phat C, Kim DH, Lee C. 2013. Occurrence of fusarium mycotoxin fumonisin B1 and B2 in animal feeds in Korea. Mycotoxin Res. 29:159-167.

Siloto EV, Oliveira EFA, Sartori JR, Fascina VB, Martins BAB, Ledoux DR, Sartori DRS. 2013. Lipid metabolism of commercial layers fed diets containing aflatoxin, fumonisin, and a binder. Poult Sci. 92:2077-2083.

SNI. 2009. SNI 3148.5:2009. Pakan konsentrat - Bagian 5: Ayam ras pedaging (Broiler concentrate). Standar Nasional Indonesia. Jakarta (Indonesia): Badan Standardisasi Nasional.

Strosnider H, Azziz-Baumgartner E, Bhat RV, Breimean R, Brune MN, DeCock K, Dilley A, Groopman J, Hell K. 2006. Workgroup report: Public health strategies for reducing aflatoxin exposure in developing countries. Environ Health Perspect. 114:1898-1903.

Suparto DAH. 2004. Situasi cemaran mikotoksin di Indonesia dan perundang undangannya. Dalam: Seminar Parasitologi dan Toksikologi Veteriner. Bogor, 20-21 April 2004. Bogor (Indonesia): Puslitbangnak. hlm. 121-126.

Weibking TS, Ledoux DR, Bermudez AJ, Rottinghaus GE. 1994. Individual and combined effects of feeding Fusarium moniliforme culture material, containing known levels of fumonisin B1, and aflatoxin B1 in the young turkey poultry. Poult Sci. 73:1517-1525.

Zain ME. 2010. Impact of mycotoxins on humans and animals. J Saudi Chem Soc. 15:129-144.

\section{DISKUSI}

\section{Pertanyaan}

1. Apakah dengan enzime dapat membunuh aflatoksin?

2. Seberapa besar kontaminasi aflatoksin di daerah tropis? Fumonisin itu terdapat pada subtropik. Apakah Karena kita mengimpor bahan dari luar?

3. Melihat dari analisis mikotoksin, apakah dalam pengambilan sampel secara visual akan menggumpal? Waktu pengambilan sampel itu musim hujan atau musim kering? 


\section{Jawaban}

1. Enzim tidak memiliki kemampuan untuk membunuh aflatoksin.

2. Hampir semua sampel mengandung fumonisin dan aflaktoksin. Padahal pakan berbasis pakan lokal ternak sapi. Hal ini kemungkinan adanya perubahan iklim.

3. Sampel yang dikandang apabila secara visual menggumpal akan dihomogenkan. 